\title{
EXPERIMENTAL INVESTIGATION OF MECHANICAL PROPERTIES AND ENERGY FEATURES OF GRANITE AFTER HEAT TREATMENT UNDER DIFFERENT LOADING PATHS
}

\author{
Junwen Zhang, Xu Chen, Hengyi Kang
}

Temperature and loading history are the two main factors that influence rock microstructure and physical and mechanical properties. To explore the influence of heat treatment and loading path on mechanical properties and energy features of granite, granite samples were first heat-treated at $25{ }^{\circ} \mathrm{C}, 300$ ${ }^{\circ} \mathrm{C}, 600{ }^{\circ} \mathrm{C}$, and $900{ }^{\circ} \mathrm{C}$. Then, 12 groups of triaxial compression experiments were placed under three loading paths, as follows: uniaxial compression, conventional triaxial compression, and confining pressure unloading. Mechanical properties and energy features in the deformation and failure process based on these experimental results were systematically compared and analyzed. Results demonstrate that Young's modulus, uniaxial compressive strength, and triaxial compressive strength increased in the temperature range of $25{ }^{\circ} \mathrm{C}$ to $300{ }^{\circ} \mathrm{C}$, but decreased in the temperature range of $300{ }^{\circ} \mathrm{C}$ to 900 ${ }^{\circ} \mathrm{C}$. Under the same loading path, the gaps among total absorbed energy, dissipated energy, and elastic strain energy widened with increasing temperature from $25^{\circ} \mathrm{C}$ to $900{ }^{\circ} \mathrm{C}$. At the same temperature, the energy features' gap under confining pressure unloading is between uniaxial and triaxial compression. The conclusions drawn in this study provide a significant reference for the design and construction of rock engineering exposed to high temperature.

Keywords: energy features; heat treatment; loading paths; triaxial compression

\section{Eksperimentalno ispitivanje mehaničkih svojstava i energetskih svojstava granita nakon toplinske obrade pri različitom načinu} opterećenja

Povijest temperature i opterećenja dva su glavna čimbenika koji utječu na mikrostrukturu stijene i fizikalna i mehanička svojstva. Da bi se istražio utjecaj toplinske obrade i opterećenja na mehanička svojstva i energetske značajke granita, uzorci granita najprije su toplinski obrađeni na $25{ }^{\circ} \mathrm{C}, 300{ }^{\circ} \mathrm{C}, 600{ }^{\circ} \mathrm{C}$ i $900^{\circ} \mathrm{C}$. Zatim je 12 skupina eksperimenata troosnog sabijanja podvrgnuto opterećenju na tri načina, kako slijedi: jednoosno sabijanje, konvencionalno troosno sabijanje i ograničeno tlačno rasterećenje. Sustavno se uspoređuju i analiziraju mehanička svojstva i značajke energije u procesu deformacije i oštećenja na temelju tih eksperimentalnih rezultata. Rezultati pokazuju da su Youngov modul, jednoosna tlačna čvrstoća i troosna tlačna čvrstoća porasli u temperaturnom području od $25^{\circ} \mathrm{C}$ do $300{ }^{\circ} \mathrm{C}$, ali su se smanjili u temperaturnom području od $300{ }^{\circ} \mathrm{C}$ do $900{ }^{\circ} \mathrm{C}$. Pod istim načinima opterećenja, razlike između ukupne apsorbirane energije, raspršene energije i elastične energije naprezanja povećale su se s porastom temperature od $25{ }^{\circ} \mathrm{C}$ do $900{ }^{\circ} \mathrm{C}$. Pri istoj temperaturi, razlika između energetskih značajki pod rasterećenjem ograničenim tlakom je između jednoosnog i troosnog sabijanja. Zaključci izneseni u ovoj studiji pružaju značajnu referencu za projektiranje i izgradnju u inženjerstvu stijena izloženih visokim temperaturama.

Ključne riječi: energetske značajke; načini opterećenja; toplinska obrada; troosno sabijanje

\section{Introduction}

In geotechnical engineering, surrounding rock may withstand high temperature, which occurs in instances such as a radioactive waste repository [1-3], enhanced geothermal system [4-6], volcano flank [7], and the reconstruction of tunnels after fire disasters. Changes in the properties of rock after undergoing high temperature may affect stability and even induce engineering accidents. In addition, the distribution features of in situ stress and excavation methods can be the other unstable factors affecting a host rock. Therefore, understanding the mechanical and other characteristics of rock after heat treatment under different loading paths is crucial.

In extant literature, the investigation of the effects of temperature on physical and mechanical properties mainly emphasize the bulk density, P- and S-wave velocity, uniaxial and triaxial strength, modulus of elasticity, Brazilian tensile strength, and Shore hardness [8]. Progressive damage and failure of rock is a continuous process of energy exchange between host rock and its surroundings. Thus, evaluating the characteristics of rock from the energy exchange perspective is a novel idea.

Temperature is one of the key factors that influence the microstructure, and the physical and mechanical properties of rocks; moreover, these properties are highly significant for rock mass classification and the design of structures either upon or inside the rock [9-11]. In addition, rock damage which has been formed previously continues existing in the rock and represents a "fingerprint" of the entire loading history [12]. The two factors, temperature and loading history, should be considered when exploring rock features. Such exploration would also be beneficial for designing or constructing some rock engineering at medium-deep and deep crust.

Based on the above analysis, the effects of heat treatment on mechanical properties under three different loading paths will be investigated. Subsequently, the energy feature of granite following heat treatment in these three loading paths will also be examined.

\section{State of the art}

Over the last several years, many scholars have researched the mechanical properties of rock after thermal treatment with experimental methods. Fredrich et al. [13] analyzed thermally cracked samples of granite, diabase, and limestone by using scanning electron microscopy. Thermally induced crack density is dependent upon the temperature, thermal expansion mismatch, thermal expansion anisotropy, initial crack porosity, and grain size. Géraud et al. [14, 15] compared the structural evolution (connected and overall porosity, and inferred permeability) of four granites, heated from $20^{\circ} \mathrm{C}$ to $700{ }^{\circ} \mathrm{C}$. The result shows that at low temperature $(T<$ $300^{\circ} \mathrm{C}$ ), the connected porosity decreases with increasing temperature. Above $300^{\circ} \mathrm{C}$, both porosities increase. 
Yavuz et al. [16, 17] investigated physical and mechanical properties, such as P-wave velocity, peak compressive strength, peak strain, and elastic modulus of marbles and limestones heated to several specific temperature levels from $25^{\circ} \mathrm{C}$ to $900{ }^{\circ} \mathrm{C}$. Microscopic examinations from thin sections showed that the damage in rocks at elevated temperatures was induced with varying severity depending on grain size, porosity, and structural and textural characteristics. Yu et al. [18] conducted triaxial compression tests on red sandstone samples previously subjected to heat treatments at $20{ }^{\circ} \mathrm{C}, 200{ }^{\circ} \mathrm{C}, 400{ }^{\circ} \mathrm{C}$, and $600{ }^{\circ} \mathrm{C}$ to study permeability evolution and the change in the properties and mechanical characteristics of the rock. The researchers found that the strength of the rock increases with heat treatments from $20{ }^{\circ} \mathrm{C}$ to $200{ }^{\circ} \mathrm{C}$ and decreases with heat treatments from $200{ }^{\circ} \mathrm{C}$ to $600{ }^{\circ} \mathrm{C}$. Yang et al. [19] investigated the thermal damage and failure mechanical behaviour of granite specimens after exposure to different high temperature treatments (200 ${ }^{\circ} \mathrm{C}, 300{ }^{\circ} \mathrm{C}, 400{ }^{\circ} \mathrm{C}, 500{ }^{\circ} \mathrm{C}, 600{ }^{\circ} \mathrm{C}, 700{ }^{\circ} \mathrm{C}$, and $800{ }^{\circ} \mathrm{C}$ ) by conducting uniaxial compression experiments, X-ray micro computed tomography observation and acoustic emission monitoring. These studies primarily focused on microscopic and mesoscopic structural changes of thermally stressed rock, and they demonstrate the clear dependence of deformation, strength, crack damage, acoustic emission behaviour, and failure mechanism of granite on high temperature treatment. Su et al. [20] performed an experimental study on the strainburst on granite treated with different high temperatures $\left(100{ }^{\circ} \mathrm{C}\right.$, $200{ }^{\circ} \mathrm{C}, 300{ }^{\circ} \mathrm{C}, 400{ }^{\circ} \mathrm{C}, 500{ }^{\circ} \mathrm{C}, 600{ }^{\circ} \mathrm{C}$, and $700{ }^{\circ} \mathrm{C}$ ) by using a novel true-triaxial rockburst test system. During the test process, a loading path was provided by keeping one free face and then loading on five other faces. The experimental results show that temperature has significant influences on the strainburst. As evident from these investigations, loading paths have a crucial effect on rock damage and failure. These studies chiefly emphasize the strength and deformation characteristics of rock subjected to high temperature. However, during the observation and testing of the strength and deformation properties of rock in these studies, the samples were treated as an isolated system or a closed system. In reality, the rock sample is an open system, which means that energy exchange occurs between the rock sample and the experimental equipment during testing. Hence, analyzing and discussing the mechanical properties of rock only from the perspective of strength and deformation without considering the energy exchange fails to meet the criteria of energy conservation law.

Numerous conventional triaxial experiments were conducted on a variety of rock samples after exposure to high temperature. Correspondingly, many theoretical models were established and extensive numerical simulations were carried out with these models. Ranjith et al. [21] conducted uniaxial compressive strength testing of Hawkesbury sandstone at various temperatures between $25^{\circ} \mathrm{C}$ and $950{ }^{\circ} \mathrm{C}$ to explore its mechanical response to significant changes in temperature. A mechanical dependence on temperature was observed, in which the compressive strength and elastic modulus for the sandstone increases with increasing temperature for temperatures approximately less than $500{ }^{\circ} \mathrm{C}$ and decreases with increasing temperature for temperatures approximately greater than $500^{\circ} \mathrm{C}$. Shao et al. [22] studied the effect of temperature on the mechanical behaviour of fine-grained Strathbogie granite under unconfined stress condition, and the stress-strain data of tested specimens were incorporated into a finite element model. Zhang et al. [23] also studied the effect of loading history on the mechanical behaviour of three types of rock. Close similarity was observed when the plastic strain distributions within numerical specimens were compared with the observed failure patterns of the experiments. Wanne et al. [24, 25] reported the first numerical modelling experiment conducted with PFC2D combining thermo-mechanical modelling, and the numerical results were compared directly with the corresponding findings from the laboratory experiment. The model captured that the behaviour of the laboratory experiment relating to macroscopic tensile failure is driven by high hoop stresses in the perimeter of the specimen. Yu et al. [26] proposed a mesostructure-based numerical model for the analysis of rock thermal cracking on the basis of elastic damage mechanics and thermalelastic theory. Subsequently, the model was validated by comparing the simulated results with well-known analytical solutions. Pan et al. [27] developed a numerical code TM-EPCA3D and employed it to study the full three-dimensional thermo-mechanical (TM) behaviour of rock pillar in Äspö Pillar Stability Experiment. The research found that the complex TM behaviour of Äspö rock pillar is significantly influenced by the complex boundary and initial conditions. Clearly, these numerical methods have been beneficial to further investigate the thermally induced behaviour of rock at both macroscopic and microscopic levels and have considerably enhanced our understanding of thermal damage and thermal cracking mechanisms. From these reports, the established numerical models, which are mainly based on the experimental results under conventional loading paths (uniaxial or triaxial compression), fail to meet the criteria in actual situations, because the mechanism in underground structure excavation, slope protection, and other rock engineering construction is primarily involved with unloading mechanical behaviour or loading in diverse stress paths.

Therefore, 12 groups of tests were conducted on granite after heat treatment under uniaxial compression, triaxial compression, and confining pressure unloading condition. Then, the effects of heat treatment on the mechanical properties and energy features under these three different loading paths were thoroughly investigated and analyzed. This work could provide a good reference for the design and construction of rock engineering in deep earth.

The remainder of this study is organized as follows. Section 3 describes the granite samples, and the experimental equipment, method, and procedure. Section 4 analyses and discusses the experimental results of mechanical properties and energy features of granite samples following heat treatment under three different loading paths. Section 5 summarizes the study.

\section{Methodology}

\subsection{Granite sample and material preparation}

In this study, granite material was prepared from a quarry in Jinjiang City, Fujian Province, P.R. China. Drilled out of the adjacent part of a large block without any macroscopic cracks, the rock cores were prepared in 
cylinders with a diameter of $25 \mathrm{~mm}$ and a height of 50 $\mathrm{mm}$. To improve the accuracy of the experiments, both end faces of the rock samples were polished with error of unevenness of less than $0.05 \mathrm{~mm}$. The density before high-temperature treatment is approximately $2.92 \mathrm{~g} \cdot \mathrm{cm}^{-3}$. The P-wave velocities of the samples were measured before heat treatment, and samples with $\mathrm{P}$-wave velocities (listed in Tab. 1) exceeding the average (4504.42 $\mathrm{m} \cdot \mathrm{s}^{-1}$ ) of $\pm 3 \%$ were taken out to ensure the uniformity of these samples. Then, the filtered granite samples were placed in a FP-25 electric high temperature furnace shown in Fig. 1(a). The designated high temperatures were $300{ }^{\circ} \mathrm{C}, 600$ ${ }^{\circ} \mathrm{C}$, and $900{ }^{\circ} \mathrm{C}$. In each case, the samples were heated at a rate of $10{ }^{\circ} \mathrm{C} / \mathrm{min}$, and kept within the desired high temperature for 4 hours. Subsequently, the furnace was turned off and the samples were naturally cooled to room temperature.

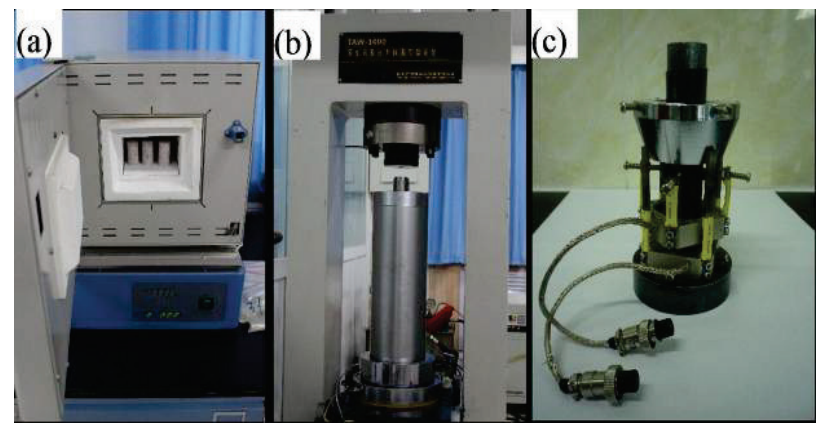

Figure 1 Experimental equipment (a) FP-25 electric high temperature furnace and, (b) TAW-1000 electro-hydraulic servo controlled triaxial testing machine, (c) Axial and radial displacement transducers

Table 1 Basis parameters of rock samples and experimental conditions

\begin{tabular}{|c|c|c|c|c|c|c|}
\hline Sample number & $\begin{array}{l}\text { Height } \\
(\mathrm{mm})\end{array}$ & $\begin{array}{l}\text { Diameter } \\
(\mathrm{mm})\end{array}$ & $\begin{array}{l}\text { Density } \\
\left(\mathrm{g} \cdot \mathrm{cm}^{-3}\right)\end{array}$ & $\begin{array}{c}\text { P-wave velocity } \\
\left(\mathrm{m} \cdot \mathrm{s}^{-1}\right)\end{array}$ & $\begin{array}{c}\text { Treated temperature } \\
\left({ }^{\circ} \mathrm{C}\right)\end{array}$ & Loading method* \\
\hline A-25 & 49.90 & 24.90 & 2.91 & 4556.48 & 25 & $\mathrm{CPU}$ \\
\hline B-25 & 49.88 & 24.92 & 2.93 & 4576.15 & 25 & CTC \\
\hline $\mathrm{C}-25$ & 49.88 & 24.92 & 2.92 & 4580.35 & 25 & $\mathrm{UC}$ \\
\hline A-300 & 47.40 & 25.00 & 2.91 & 4443.64 & 300 & $\mathrm{CPU}$ \\
\hline B-300 & 48.22 & 24.81 & 2.91 & 4479.21 & 300 & CTC \\
\hline C-300 & 47.86 & 25.02 & 2.93 & 4498.90 & 300 & $\mathrm{UC}$ \\
\hline A-600 & 47.40 & 24.96 & 2.91 & 4468.66 & 600 & $\mathrm{CPU}$ \\
\hline B-600 & 49.74 & 24.90 & 2.92 & 4542.47 & 600 & CTC \\
\hline C-600 & 47.92 & 24.80 & 2.91 & 4467.04 & 600 & $\mathrm{UC}$ \\
\hline A-900 & 48.02 & 25.01 & 2.91 & 4446.30 & 900 & $\mathrm{CPU}$ \\
\hline B-900 & 48.24 & 25.00 & 2.93 & 4466.67 & 900 & CTC \\
\hline C-900 & 49.12 & 24.94 & 2.91 & 4527.19 & 900 & $\mathrm{UC}$ \\
\hline
\end{tabular}

*CPU: confining pressure unloading; CTC: conventional triaxial compression; UC: uniaxial compression

\subsection{Experimental equipment}

All the experiments on granite after high-temperature $\left(25^{\circ} \mathrm{C}-900{ }^{\circ} \mathrm{C}\right)$ under uniaxial compression, triaxial compression, and confining pressure unloading condition were conducted using a home-designed TAW-1000 electro-hydraulic servo controlled triaxial testing machine, as shown in Fig. 1(b). The maximum axial loading capacity is $1000 \mathrm{kN}$, and the maximum confining pressure loading capacity is $70 \mathrm{MPa}$. In addition, the applied load can be fully-controlled digitally and the testing data can be automatically collected by a computer. Thus, the experiments of the deformation and failure of rock samples under complex loading paths can be taken on the equipment.

The axial and radial displacement transducers used in this research are illustrated in Fig. 1(c). The measuring ranges of the axial and radial transducers are 4.0 and 2.0 $\mathrm{mm}$, respectively, and their reading accuracy is $\pm 1 \%$ at room temperature. The transducers can be used to record axial and radial strains simultaneously with the axial stress and confining pressure.

\subsection{Experimental method and procedure}

All granite samples after high temperature treatment were divided into three groups with their treated temperature. Included in each group are three sub-groups loaded under uniaxial compression, conventional triaxial compression, and confining pressure unloading condition.

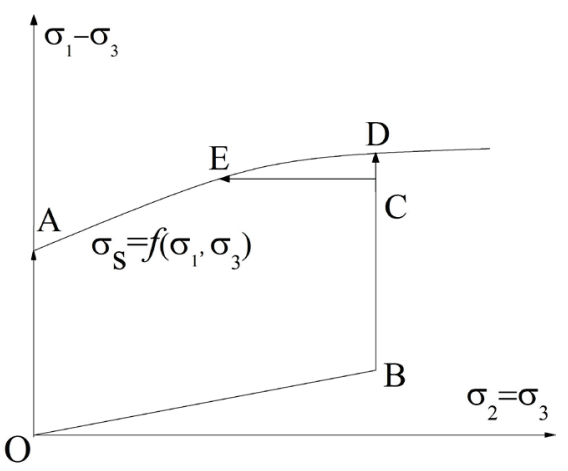

Figure 2 Sketch of three loading paths for granite samples

These three kinds of loading paths are shown in Fig. 2. The function $\sigma_{s}=f\left(\sigma_{2}, \sigma_{3}\right)$ is the failure criteria. For samples under uniaxial compression, the loading path in Fig. 2 is OA. Under conventional triaxial compression (shown as OBD in Fig. 2), the confining pressure was first applied on the sample by applying hydrostatic pressure $\sigma_{1}=\sigma_{2}$ to the designated value of $30 \mathrm{MPa}$. Then, the axial displacement was servo-controlled at a constant rate of $0.04 \mathrm{~mm} / \mathrm{min}$ to apply deviatoric stress until failure occurred. In the loading path of confining loading (shown as OBCE in Fig. 2), the confining pressure was unloaded before peak stress with the deviatoric stress remaining at about $80 \%$ of the peak stress. Note that the granite is very brittle, thereby resulting in an extremely short unloading stage. Tests with uniaxial compression and triaxial compression were conducted before the confining pressure unloading tests, because they can provide basic 
data on the rock and the stress level of unloading. The loading methods of each sample are illustrated in Tab. 1.

\subsection{The method to analyze energy features}

The deformation and failure process of rock sample under compression is assumed to be a closed system with no heat exchange from the outside. According to the principal law of thermodynamics, the rock sample's total absorbed energy $U$ per unit volume is

$$
U=U^{e}+U^{d}
$$

where $U^{e}$ represents the releasable elastic strain energy stored in the per unit volume of rock sample, and forms in the elastic deformation stage. After the external force is unloaded, the elastic strain energy can recover the elastic deformation. $U^{d}$ is the dissipated energy per unit volume of the rock sample, mainly used for internal damage and plastic deformation. The change of the dissipated energy satisfies the second law of thermodynamics.

The relationship between elastic strain energy $U^{e}$ and dissipated energy $U^{d}$ per unit volume of rock is shown in Fig. 3. The shaded and unshaded parts under the stressstrain curve represent the releasable elastic strain energy stored in the rock sample and the dissipated energy, respectively.

In principal stress space, the total absorbed energy $U$ per unit volume can also be expressed by [28]

$$
\begin{aligned}
& U=\int \sigma_{1} \mathrm{~d} \varepsilon_{1}+\int \sigma_{2} \mathrm{~d} \varepsilon_{2}+\int \sigma_{3} \mathrm{~d} \varepsilon_{3} \\
& U^{e}=\frac{1}{2} \sigma_{1} \varepsilon_{1}^{e}+\frac{1}{2} \sigma_{2} \varepsilon_{2}^{e}+\frac{1}{2} \sigma_{3} \varepsilon_{3}^{e} \\
& \varepsilon_{i}^{e}=\frac{1}{E_{i}}\left[\left(\sigma_{i}-v_{i}\left(\sigma_{j}+\sigma_{k}\right)\right]\right.
\end{aligned}
$$

where $\sigma_{i}, \sigma_{j}$, and $\sigma_{k}(i, j, k=1,2,3)$ are principal stresses, and $\varepsilon_{i}$ and $\varepsilon_{i}^{e}$ are the strain and the elastic strain in the direction of the principal stress, respectively. $v_{i}$ is Poisson's ratio, and $E_{i}$ is the unloading elastic modulus.

When the rock samples are under uniaxial compression, the total absorbed energy $U$ per unit volume can be rewritten as

$$
\begin{aligned}
& U=\int \sigma_{1} \mathrm{~d} \varepsilon_{1}=\sum_{i=0}^{n} \frac{1}{2}\left(\sigma_{1 i+1}+\sigma_{1 i}\right)\left(\varepsilon_{1 i+1}-\varepsilon_{1 i}\right) \\
& U^{e}=\frac{1}{2} \sigma_{1} \varepsilon_{1}^{e}=\frac{\sigma_{1}^{2}}{2 E}
\end{aligned}
$$

where $\sigma_{1 i}$ and $\varepsilon_{1 i}$ are the $i^{\text {th }}$ values on the axial stressstrain curve, and both the initial stress $\sigma_{10}$ and strain $\varepsilon_{10}$ are zero. $E$ is the elastic modulus, which is the ratio of stress to strain in the elastic deformation stage.

When the rock samples are under conventional triaxial compression, the second principal stress is equal to the third principal stress, i.e., $\sigma_{2}=\sigma_{3}$. Then, Eq. (2) can be re-expressed by

$$
U=\int \sigma_{1} \mathrm{~d} \varepsilon_{1}+2 \int \sigma_{3} \mathrm{~d} \varepsilon_{3}
$$

In the confining pressure unloading tests in this study, the elastic strain energy and the total absorbed energy can be calculated by the same formulas, namely, Eq. (3) and Eq. (7), as performed under triaxial compression. However, when calculating the elastic strain energy, elastic modulus should be the unloading elastic modulus, which is 1.05 times the value of the elastic modulus.

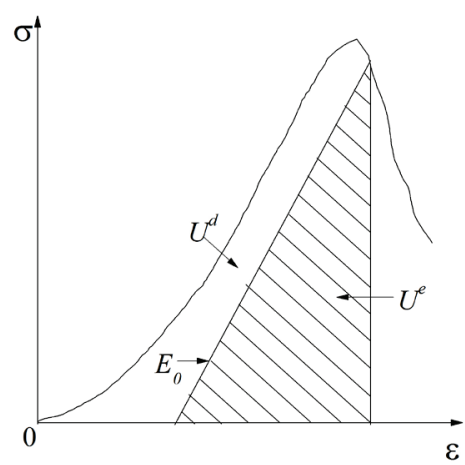

Figure 3 Relationship between elastic strain energy and dissipated energy of rock sample

\section{Result analysis and discussion \\ 4.1 Mechanical properties}

Fig. 4 illustrates the deviatoric stress-axial strain and stress-radial strain curves of granite samples after heat treatment under three different loading paths. Based on the division method by Wang et al. [29], the complete stress-strain process of uniaxial or triaxial compression can be characterized into several stages: initial compression, linear elastic deformation, non-linear elastic deformation, and strain softening stage. From Fig. 4(a), the stress-strain curves of different granite samples following heat treatment under uniaxial compression conform to the aforementioned division. However, the curves of the samples have noticeable changes in their tracing patterns with increasing treated high-temperature:

1) The curves have a longer initial compression stage, i.e. the total axial strain of the initial compression stage increases with the treated temperature.

2) The uniaxial compressive strength, the triaxial compressive strength and the Young's modulus of the samples (shown in Tab. 2) initially increase and then decrease. The experimental result shows that, with the treated temperature increasing from room temperature to $300{ }^{\circ} \mathrm{C}$, the growth rates of uniaxial compressive strength and Young's modulus are $8.84 \%$ and $1.58 \%$ respectively (from 120.78 MPa to $131.46 \mathrm{MPa}$ in uniaxial compressive strength and from 27.81 GPa to $28.25 \mathrm{GPa}$ in Young's modulus). This outcome is caused by the rock samples losing their inner water through evaporation, causing closure of microcracks, enhancement of density, improvement of mineral particle cementation, and reinforcement of mechanical properties. With the treated temperature growing from $300{ }^{\circ} \mathrm{C}$ to $900{ }^{\circ} \mathrm{C}$, the uniaxial compressive strength and Young's modulus fall respectively to $31.11 \mathrm{MPa}$ and $5.02 \mathrm{GPa}$, and the reduction rates (compared to room temperature) are $74.24 \%$ and $81.95 \%$, respectively. Such result is 
obtained because, when the treated temperature is greater than $300{ }^{\circ} \mathrm{C}$, different mineral particles in the granite sample have dissimilar coefficients of thermal expansion, resulting in the increase in thermal stress. Once the thermal stress exceeds the ultimate strength of the materials, the microcracks and micropores will initiate, propagate, and connect. This phenomenon of thermal damage is manifested as the degradation of the mechanical properties of rock.

3) The non-linear elastic deformation stages in all temperature cases are quite short for granite samples.

4) At the strain softening stage, deviatoric stress declines rapidly in an extremely small axial strain, which shows evident characteristic of brittle failure.

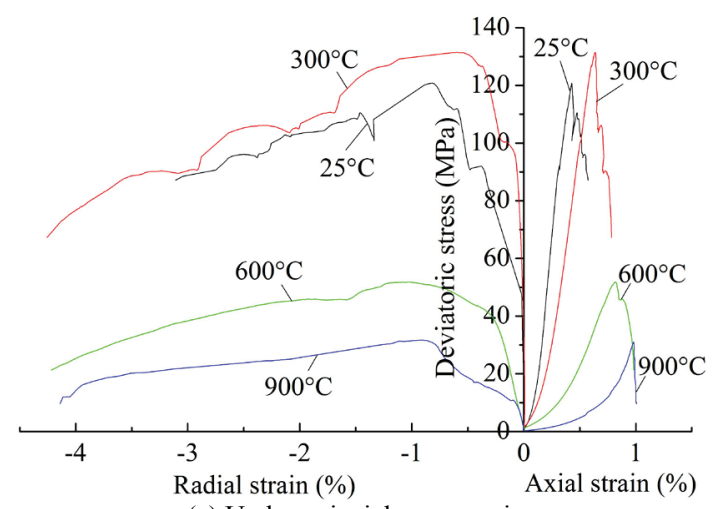

(a) Under uniaxial compression

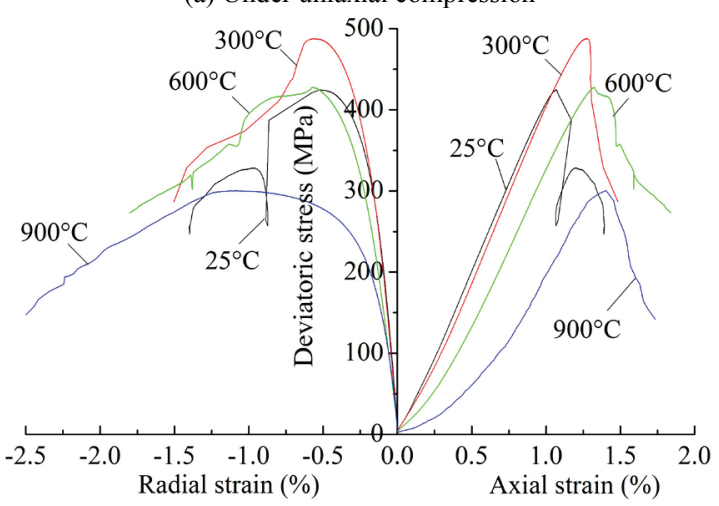

(b) Under conventional triaxial compression

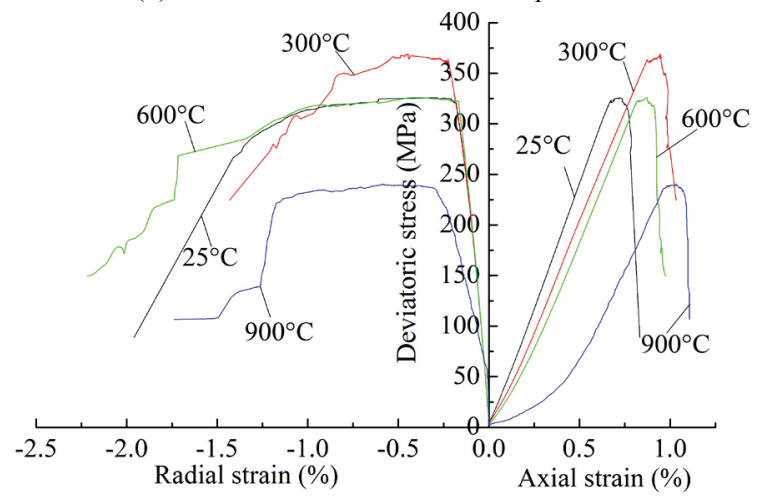

(c) Under confining pressure unloading condition

Figure 4 Deviatoric stress-axial strain and-radial strain curves of granite after high-temperature under three different loading paths

Comparison between Fig. 4(a) and Fig. 4(b) clearly shows that the triaxial compressive strength in all hightemperature treated cases is considerably larger than the uniaxial compressive strength, indicating that the confining pressure enhances the bearing capacity of these granite samples. Moreover, the effect of the strength enhancement is more apparent with a higher treatment temperature. The experimental results show that the triaxial compressive strength of the granite sample without heat treatment is approximately 3.5 times larger than the uniaxial compressive strength, while it is about $3.7,8.25$, and 9.65 times larger than the uniaxial compressive strength after $300{ }^{\circ} \mathrm{C}, 600{ }^{\circ} \mathrm{C}$, and $900{ }^{\circ} \mathrm{C}$ high-temperature treatment. In addition, the slope of the stress-axial strain under triaxial compression varies with the treated temperature in the same tendency it exhibited under uniaxial compression, i.e., increases from room temperature to $300{ }^{\circ} \mathrm{C}$ and then decreases from $300{ }^{\circ} \mathrm{C}$ to $900{ }^{\circ} \mathrm{C}$. This variation trend is also caused by the evaporation of inner water and the difference of the coefficients of thermal expansion of mineral particles. The inner water evaporation induces the expansion of air in the micropores and microcracks, which makes the microcracks get closed and makes the rock sample get denser.

Fig. 4(c) indicates that before confining pressure unloading, the stress-strain curves have similar variation tendency as in Fig. 4(b). After unloading the confining pressure and maintaining the deviatoric stress as far as possible, the axial strain begins to grow in the horizontal, but this plateau region in the confining pressure unloading process for granite is quite short compared with the rock samples as reported by $\mathrm{Yu}$ et al. [30]. The radial strain in the confining pressure unloading process increases rapidly until failure. Comparing Fig. 4(c) with Fig. 4(a) and Fig. 4(b), when the granite samples after heat treatment under confining pressure unloading conditions lose their bearing capacity, the most rapid stress drop is observed in the three loading paths, indicating that the failure is the most brittle. From the perspective of different treated temperatures, the evolution rules of stress-strain have roughly similar form under the loading path of confining pressure unloading.

Table 2 Mechanical characteristic values of granite samples

\begin{tabular}{|c|c|c|c|c|}
\hline $\begin{array}{c}\text { Sample } \\
\text { number }\end{array}$ & $\begin{array}{c}\text { Treated } \\
\text { temperature } \\
\left({ }^{\circ} \mathrm{C}\right)\end{array}$ & $\begin{array}{c}\text { Loading } \\
\text { method* }\end{array}$ & $\begin{array}{c}\text { Peak } \\
\text { stress } \\
(\mathrm{MPa})\end{array}$ & $\begin{array}{c}\text { Young's } \\
\text { modulus } \\
(\mathrm{GPa})\end{array}$ \\
\hline A-25 & 25 & CPU & - & 42.539 \\
\hline B-25 & 25 & CTC & 424.75 & 43.646 \\
\hline C-25 & 25 & UC & 120.78 & 35.069 \\
\hline A-300 & 300 & CPU & - & 45.108 \\
\hline B-300 & 300 & CTC & 487.91 & 44.927 \\
\hline C-300 & 300 & UC & 131.46 & 30.151 \\
\hline A-600 & 600 & CPU & - & 41.867 \\
\hline B-600 & 600 & CTC & 427.61 & 42.136 \\
\hline C-600 & 600 & UC & 51.83 & 10.638 \\
\hline A-900 & 900 & CPU & - & 36.514 \\
\hline B-900 & 900 & CTC & 300.61 & 37.235 \\
\hline C-900 & 900 & UC & 31.11 & 4.719 \\
\hline
\end{tabular}

*CPU: confining pressure unloading; CTC: conventional triaxial compression; UC: uniaxial compression

\subsection{Energy features \\ 4.2.1 Energy features under uniaxial compression}

Fig. 5 shows the complete stress-strain curves, evolutions of total energy, elastic strain energy, and dissipated energy of granite after high-temperature under uniaxial compression. In this figure, the methods in Sec. 3.4 are employed to analyse the features of the elastic 
strain energy, the dissipated energy, and the total absorbed energy.

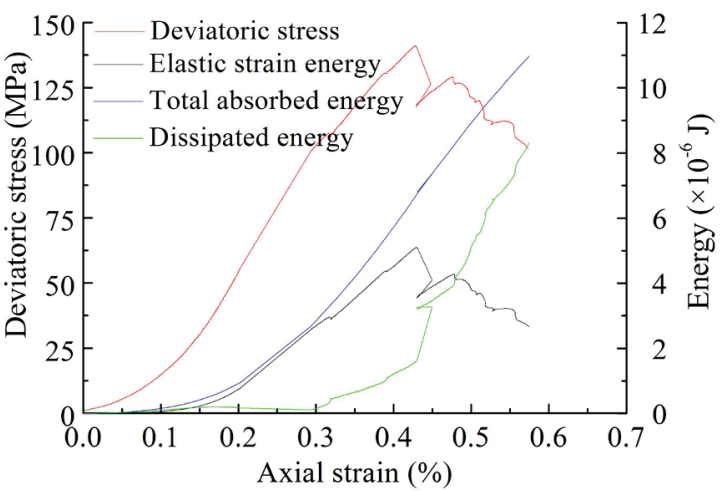

(a) $25^{\circ} \mathrm{C}$

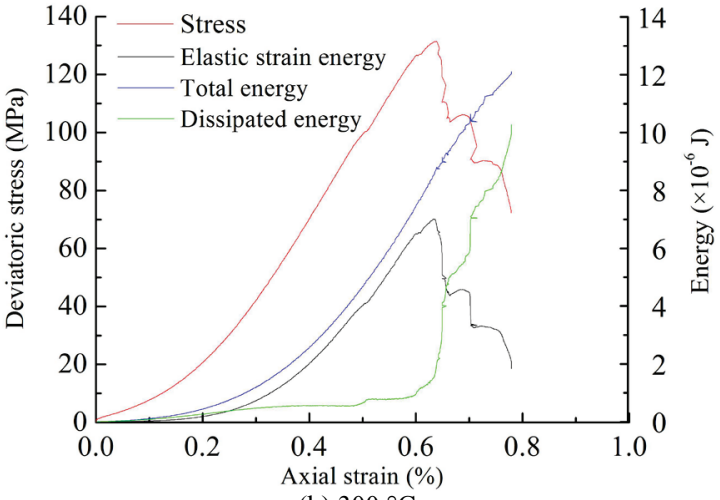

(b) $300{ }^{\circ} \mathrm{C}$

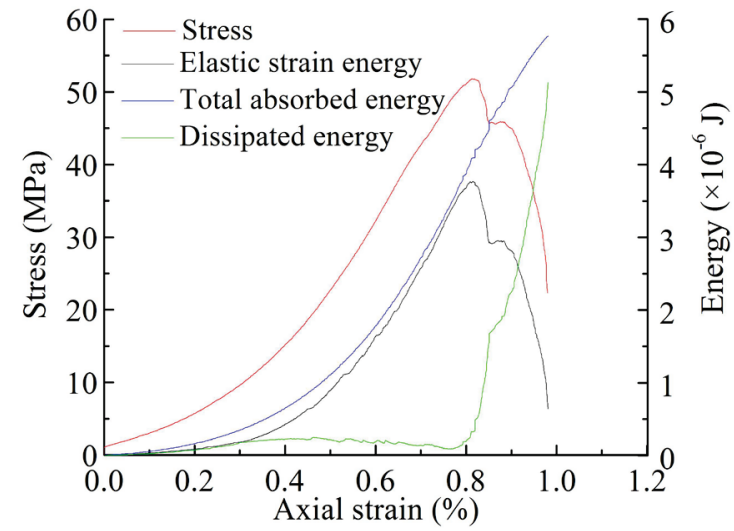

(c) $600{ }^{\circ} \mathrm{C}$

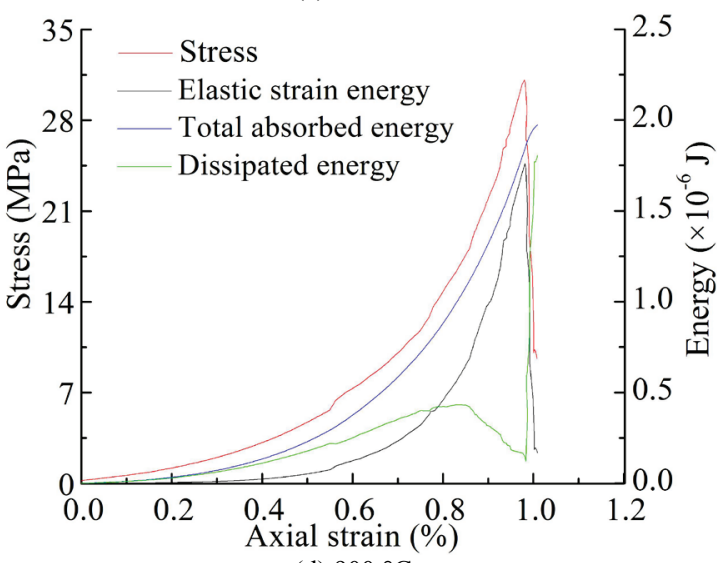

(d) $900^{\circ} \mathrm{C}$

Figure 5 Energy evolution of granite after heat treatment under uniaxial compression

As evident from Fig. 5, for a certain treated high temperature, the granite samples have different trends of energy evolution at each stage of the stress-strain process. In the initial compression and the linear elastic deformation stages, the energy absorbed from external work almost completely transforms into recoverable elastic strain energy stored in the rock sample. In the nonlinear deformation stage prior to peak stress, most of the absorbed energy is stored as elastic strain energy in the rock samples. Simultaneously, the rest of the absorbed energy is gradually dissipated during crack formation, propagation, connection, and nucleation. At this stage, the elastic strain energy reaches its peak. As presented in Tab. 3 , the peak values of the elastic strain energy $U^{e}$ at different treated temperatures are $5.06 \times 10^{-6} \mathrm{~J}$, $7.01 \times 10^{-6} \mathrm{~J}, 3.20 \times 10^{-6} \mathrm{~J}$, and $1.73 \times 10^{-6} \mathrm{~J}$, respectively. The peak value of $U^{e}$ initially increases and then decreases with the temperature from room temperature to $900{ }^{\circ} \mathrm{C}$, and the maximum value of these peaks of $U^{e}$ occurs at the heat-treated temperature of $300{ }^{\circ} \mathrm{C}$.

Table 3 Particular values of energy features of granite samples after heat treatment under uniaxial compression

\begin{tabular}{|c|c|c|c|c|}
\hline 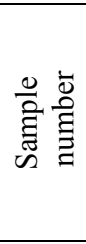 & 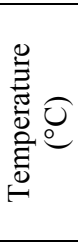 & $\begin{array}{c}\text { Total } \\
\text { absorbed } \\
\text { energy at the } \\
\text { peak stress } \\
U_{0}^{\text {peak }} \\
\left(\times 10^{-6} \mathrm{~J}\right)\end{array}$ & $\begin{array}{c}\text { Dissipated } \\
\text { energy after } \\
\text { peak stress } U_{d}^{a} \\
\left(\times 10^{-6} \mathrm{~J}\right)\end{array}$ & $\begin{array}{l}\text { Peak value of } \\
\text { elastic strain } \\
\text { energy } U^{e} \\
\left(\times 10^{-6} \mathrm{~J}\right)\end{array}$ \\
\hline C-25 & 25 & 10.92 & 8.22 & 5.06 \\
\hline $\mathrm{C}-300$ & 300 & 12.08 & 10.24 & 7.01 \\
\hline C-600 & 600 & 5.74 & 5.16 & 3.20 \\
\hline C-900 & 900 & 1.96 & 1.78 & 1.73 \\
\hline
\end{tabular}

In the strain softening stage of brittle failure, an inclined macrocrack formed inside the rock sample and structural failure occurs, leading to dramatic decline in the stress. The accumulative elastic strain energy stored in the rock sample in the former stages is released instantly and transforms into rapidly increasing dissipated energy. Aside from the peak values of the recoverable elastic strain energy of granite samples after high-temperature under uniaxial compression, Tab. 3 also presents the total absorbed energy at the stress peak points and the dissipated energy after the stress peaks, which are designated as $U_{0}^{\text {peak }}$ and $U_{d}^{a}$, respectively. Both $U_{0}^{\text {peak }}$ and $U_{d}^{a}$ also increase initially then decrease with the increasing heat-treated temperature. These results are also caused by the energy transformation being closely related to the inner structure change of the granite sample during uniaxial loading, and the changes in the microstructure of the granite sample before loading due to the high temperature treatment. This view has been proved by Géraud et al. [13]. By measuring the connected and overall porosity with X-ray computerized tomography, they found that the thermal stress influences the texture flaws of granite and affects its mechanical characteristics.

\subsubsection{Energy features under conventional triaxial compression}

Fig. 6 displays the evolution of elastic strain energy, dissipated energy, and the total absorbed energy of granite after high-temperature under triaxial compression. From 
Fig. 6, under conventional triaxial compression, the stress-strain curves and the elastic strain energy evolution curves clearly have a similar varying trend with that under uniaxial compression.

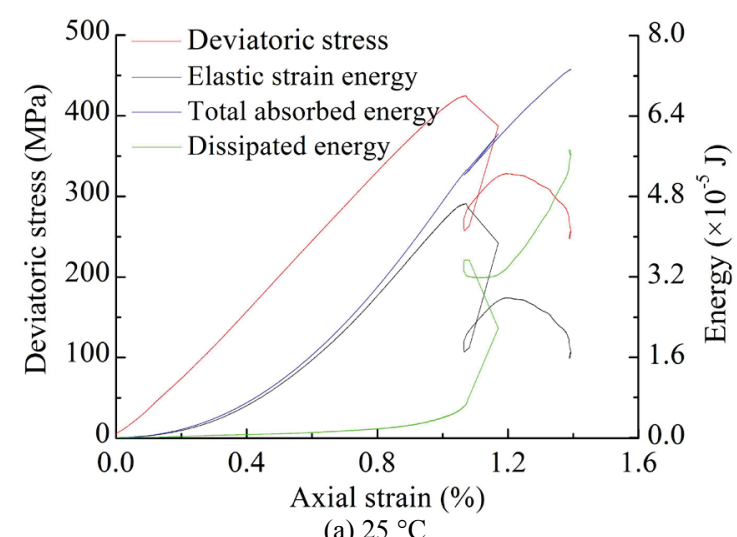

(a) $25^{\circ} \mathrm{C}$

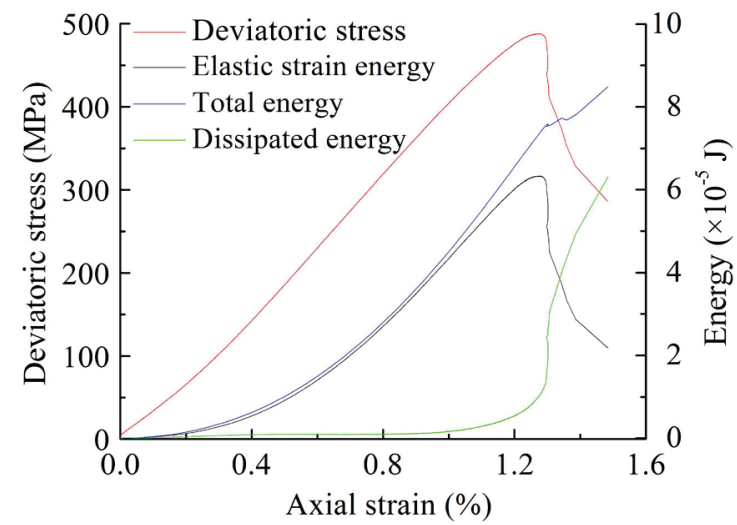

(b) $300{ }^{\circ} \mathrm{C}$

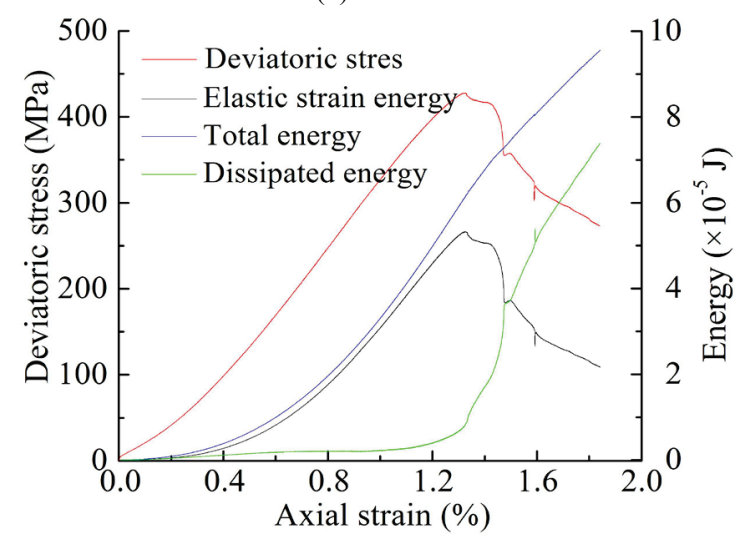

(c) $600{ }^{\circ} \mathrm{C}$

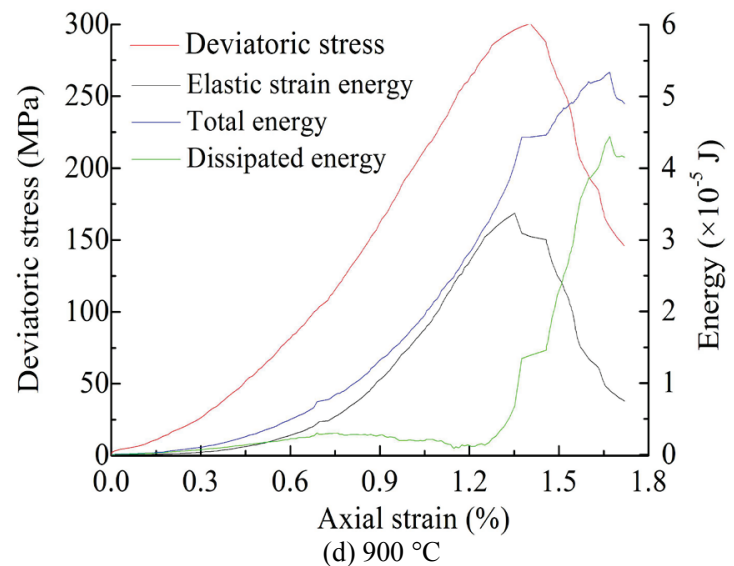

Figure 6 Energy evolution of granite after heat treatment under triaxial compression
Before the non-linear elastic deformation stage, the recoverable elastic strain energy stored in the rock samples increases with the axial stress, and the ratio of elastic strain energy to total absorbed energy also increases. After the stress-strain curves reach the prepeak nonlinear deformation stage, part of the absorbed energy dissipates because of the plastic deformation, and the propagation and nucleation of microcracks. At this stage, although both the elastic strain and the dissipated energies increase, the ratio of elastic strain energy to total absorbed energy decreases. The recoverable elastic strain stored in the rock sample reaches its peaks at a moment before the stress peak. As shown in Table 4, the peaks of the elastic strain energy $U^{e}$ of the granite samples after high-temperature treatment of $25^{\circ} \mathrm{C}, 300{ }^{\circ} \mathrm{C}, 600{ }^{\circ} \mathrm{C}$, and $900{ }^{\circ} \mathrm{C}$ are $4.65 \times 10^{-5} \mathrm{~J}, 6.32 \times 10^{-5} \mathrm{~J}, 5.30 \times 10^{-5} \mathrm{~J}$, and $3.36 \times 10^{-5} \mathrm{~J}$, respectively. Their maximum value of also occurs at the treated high temperature of $300{ }^{\circ} \mathrm{C}$. This phenomenon is the same as under uniaxial compression, and the reason is also that the rock sample structure was changed by the thermal stress. When the stress-strain curves reach their peaks, the recoverable strain energy stored in rock samples gradually dissipates as the propagation of microcracks progresses.

Table 4 Particular values of energy features of granite samples after heat treatment under triaxial compression

\begin{tabular}{|c|c|c|c|c|}
\hline $\begin{array}{c}\text { Sample } \\
\text { number }\end{array}$ & $\begin{array}{c}\text { Temperature } \\
\left({ }^{\circ} \mathrm{C}\right)\end{array}$ & $\begin{array}{c}\text { Total } \\
\text { absorbed } \\
\text { energy at } \\
\text { the peak } \\
\text { stress } U^{\text {peak }} \\
\left(\times 10^{-5} \mathrm{~J}\right)\end{array}$ & $\begin{array}{c}\text { Dissipated } \\
\text { energy } \\
\text { after peak } \\
\text { stress } U_{d}^{a} \\
\left(\times 10^{-5} \mathrm{~J}\right)\end{array}$ & $\begin{array}{c}\text { Peak value } \\
\text { of elastic } \\
\text { strain } \\
\text { energy } U^{e} \\
\left(\times 10^{-5} \mathrm{~J}\right)\end{array}$ \\
\hline B-25 & 25 & 7.31 & 5.69 & 4.65 \\
\hline B-300 & 300 & 8.43 & 6.38 & 6.32 \\
\hline B-600 & 600 & 7.31 & 5.23 & 5.30 \\
\hline B-900 & 900 & 5.31 & 4.42 & 3.36 \\
\hline
\end{tabular}

As shown in Fig. 6, unlike under uniaxial compression, a slight fluctuation occurs on the curves of total absorbed energy when the stress-strain curves reach their peaks. On the one hand, this occurs principally because macroscopic fractures form when the stressstrain curves of the samples reach their stress peaks, leading to a sharp increase in circumferential strain. The negative work done by sample expansion plays the dominant role. On the other hand, given the restriction of confining pressure, a certain amount of energy remains stored inside the rock in the stage of residual deformation, but such energy can be negligible compared with the dissipated energy. During this stage, most of the total absorbed energy is transformed into dissipated energy, i.e., the absorbed energy dissipated with shear sliding failure of the rock sample.

From Tab. 4, similar to the outcome under uniaxial compression, in the loading path of triaxial compression the total absorbed energy at the peak stress $U_{0}^{\text {peak }}$ and the dissipated energy after peak stress $U_{d}^{a}$ increase with the treated temperature increase from $25{ }^{\circ} \mathrm{C}$ to $300{ }^{\circ} \mathrm{C}$, and then decrease with the temperature increase from $300{ }^{\circ} \mathrm{C}$ to $900{ }^{\circ} \mathrm{C}$. 


\subsubsection{Energy features under confining pressure unloading}

Fig. 7 shows the energy evolution of granite after high-temperature under confining pressure unloading. After the confining pressure was unloaded, the stressstrain curves began to fluctuate. In experiments, the deviatoric stress can hardly be kept at $80 \%$ of the peak stress. The result significantly differs from the experimental result on sandstone samples [30]. Such dissimilarity is because granite is much more brittle than sandstone. Before confining pressure unloading, the total absorbed energy and the elastic strain energy increase dramatically with the axial strain, indicating that most of the energy absorbed from the radial and axial loading transforms into the elastic strain energy and is finally stored inside the granite sample. By contrast, the dissipated energy before confining pressure unloading only rises slightly with the axial strain. All the energy features before confining unloading show similar trends as those under conventional triaxial compression.

When the confining pressure begins to unload, the total absorbed energy continues to increase slightly with the axial strain, suggesting that, even though the unloading confining pressure releases some energy, the rock samples still absorb energy from the axial load. At this phase, the energy features show significantly different trends from that in the loading path of triaxial compression. The total absorbed energy of the rock sample gradually decreases, because the unloading confining pressure leads to radial expansion of the rock sample, which does negative work to the oil in the triaxial confining pressure cell. The elastic strain energy increases slightly after confining pressure unloading and reaches its peak when the confining pressure was unloaded to a certain value. The peak values of the elastic strain energy are $23.51 \times 10^{-6} \mathrm{~J}, 34.48 \times 10^{-6} \mathrm{~J}, 27.16 \times 10^{-6} \mathrm{~J}$, and $17.35 \times 10^{-6} \mathrm{~J}$, which also increases with the treated temperature from $25^{\circ} \mathrm{C}$ to $300{ }^{\circ} \mathrm{C}$ and decreases with the treated temperature from $25{ }^{\circ} \mathrm{C}$ to $900{ }^{\circ} \mathrm{C}$. In addition, the growth rate in the dissipated energy rises in the process of confining pressure unloading. The aforementioned variation trends of energy features imply that microcracks constantly propagate, grow, and connect with the coupling effect of axial loading and radial confining pressure unloading in all of the high-temperature treated rock samples.

After continuing to fluctuate for a while, the stressstrain curves suddenly drop in a very minute range of axial strain, because the release of the confining pressure causes the samples to lose bearing capacity. At this phase, the elastic strain energy stored in the rock almost instantaneously transforms into dissipated energy, and the dissipated energy increases sharply. The sudden energy transformation provides indirect evidence that the brittle characteristics of the granite samples treated with high temperature from $25^{\circ} \mathrm{C}$ to $900{ }^{\circ} \mathrm{C}$ are remarkably obvious.

In practical rock engineering, elastic energy is absorbed from underground stress, which would release during excavation. Ultimately, the dissipated energy leads to the instability or failure of the surrounding rock mass. For deep earth geotechnical engineering, underground stress is relatively high, thereby allowing the rock mass to save much more energy. Once the excavation is conducted, the energy would release immediately. This process is the basic mechanism of some dynamic disasters of rock mass, such as rock bursts and landslides.

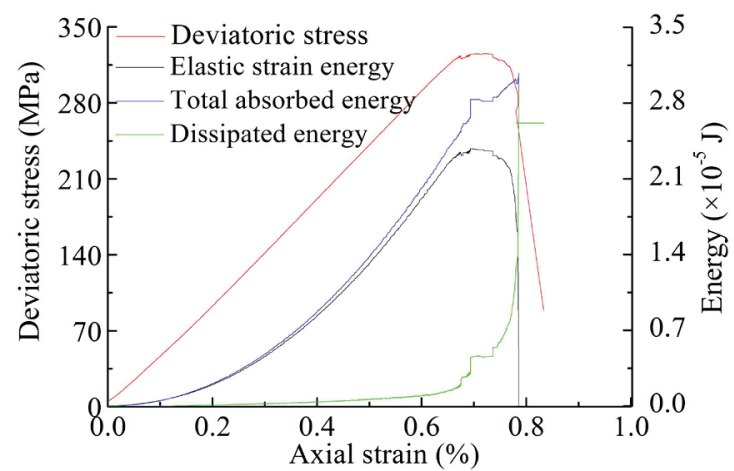

(a) $25^{\circ} \mathrm{C}$

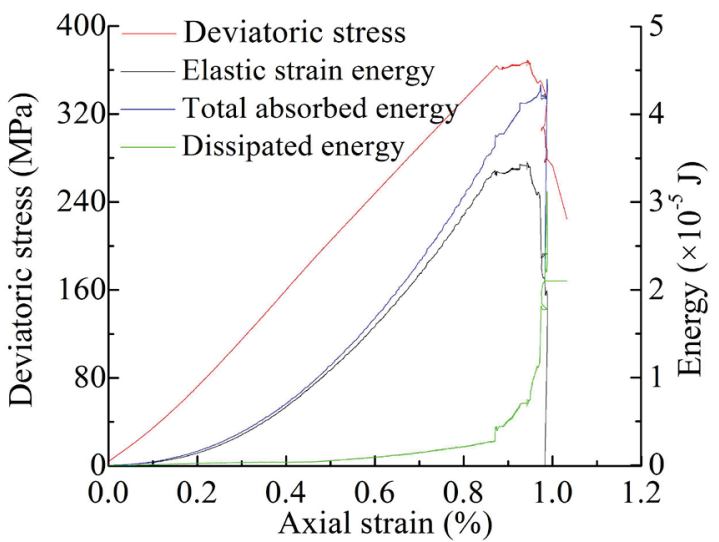

(b) $300{ }^{\circ} \mathrm{C}$

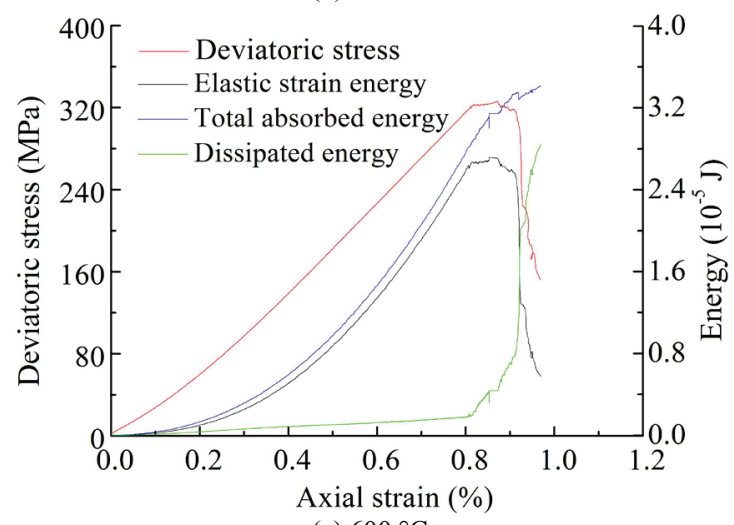

(c) $600{ }^{\circ} \mathrm{C}$

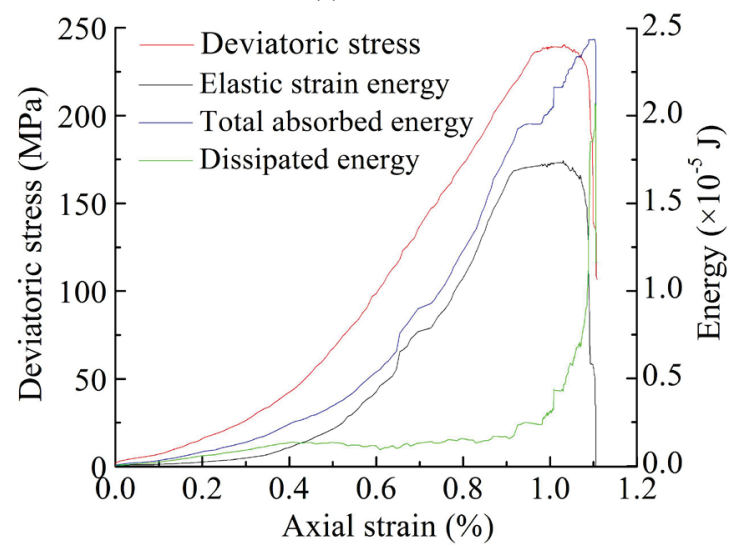

(d) $900{ }^{\circ} \mathrm{C}$

Figure 7 Energy evolution of granite after heat treatment under confining pressure unloading 
The deformation law of the dissipated energy of the rock during the unloading confining pressure test is shown in Fig. 8. As seen from this figure, at the beginning of the said test, the rock is undergoing plastic deformation. At that time, the samples release less energy and growth is relatively slow. When unloading to a certain degree, the more serious the internal damage of the rock becomes, the more energy the sample releases. The dissipated energy has grown explosively in this stage. This outcome also clearly shows the brittle failure under unloading confining pressure test. Comparing the change of the dissipated energy with the confining pressure under different temperatures, results show that the samples failed at $300{ }^{\circ} \mathrm{C}$ when the confining pressure was unloaded at the minimum level. The higher the temperature is, the more dissipated is the release. The peak of the dissipated energy initially increased and then decreased.

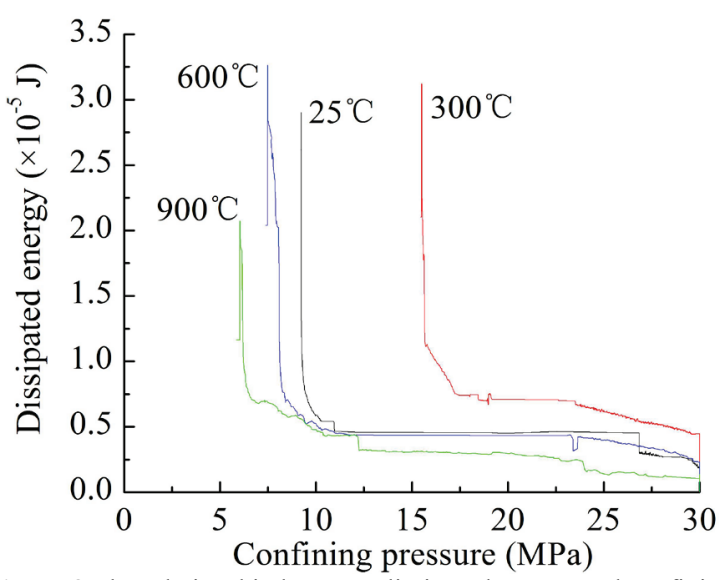

Figure 8 The relationship between dissipated energy and confining pressure of granite after high-temperature under confining pressure

\subsection{Influence of temperature on characteristic energy values}

Fig. 9 shows the characteristic energy values of granite samples following heat treatment after failure under different loading paths. As observed from this figure, the total absorbed energy, the dissipated energy, and the peak values of elastic strain energy after failure have a variation tendency of increasing first and then decreasing with the treated temperature. Moreover, the peaks of these three characteristic energy values under all of the three different loading paths occur in the case of $300{ }^{\circ} \mathrm{C}$. These variation tendencies of characteristic energy values are quite similar to the evolution tendency of strength and Young's modulus. Such finding is not coincidental, but because the evaporation of inner water and strengthening of parts of mineral grains reinforces the granite samples under high-temperature treatment of $300{ }^{\circ} \mathrm{C}$, making it absorb more energy from the external forces. Correspondingly, the dissipated and elastic energies are relatively greater than samples without temperature treatment. However, with the treated temperature continually increasing (more than $300{ }^{\circ} \mathrm{C}$ ), some thermal cracks form in the rock samples, and certain minerals even experience particular chemical reactions under high temperature. These changes of the rock microstructure would weaken its ability to store energy.
As shown in Fig. 9, the change of energy data with treated temperature in all three different loading paths could be fitted with quadratic functions.

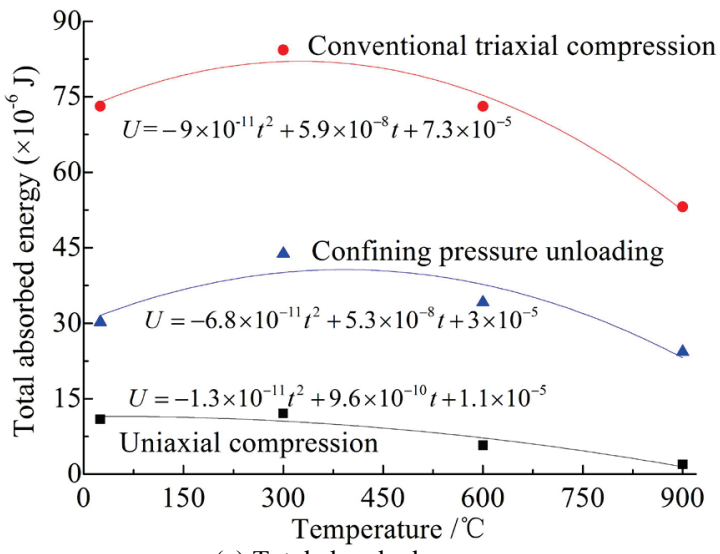

(a) Total absorbed energy

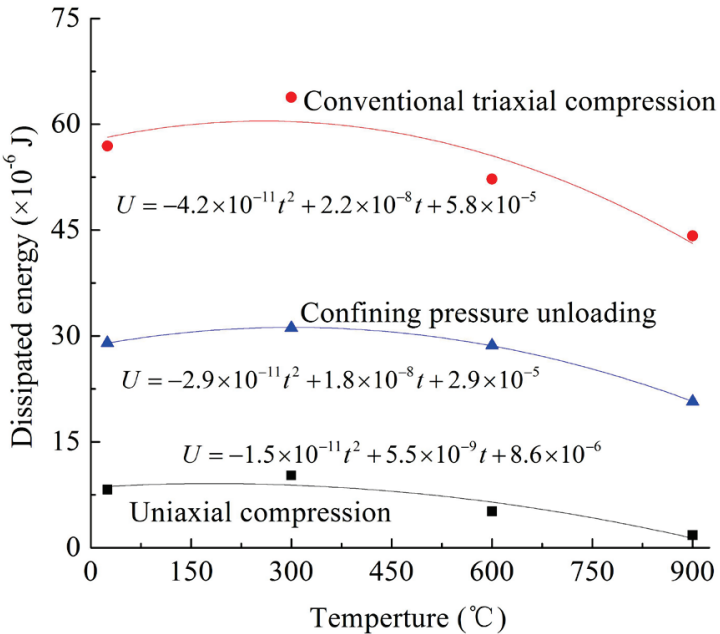

(b) Dissipated energy

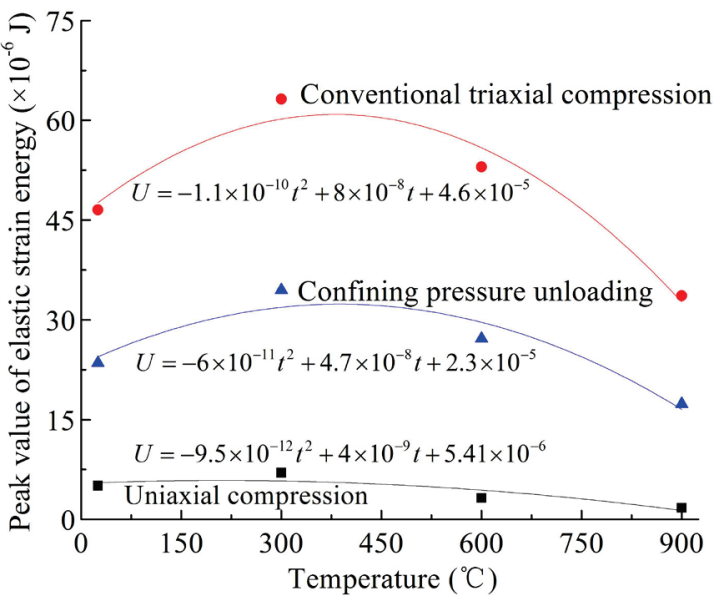

(c) Peak value of elastic strain energy

Figure 9 Characteristic energy values of granite samples after heat treatment after failure under different loading paths

The total energy of the rock sample absorbed from external forces transforms to elastic strain energy and dissipated energy, and the distribution ratio of the two parts would affect rock deformation. For example, a sudden release of elastic strain energy would lead to instability and even failure of surrounding rock in some deep earth engineering [31-34]. Thus, in-depth analysis of the relationship between the ratio of elastic strain energy to total absorbed energy $U^{e} / U$ and the treated 
temperature under three different loading paths is required. As presented in Fig. 10, with a certain treated temperature, the ratio $U^{e} / U$ is highest under confining pressure unloading condition, followed by the ratio under triaxial compression, and then ratio under uniaxial compression. That finding means that confining pressure could multiply the amount of absorbed energy and raise the efficiency of energy accumulation. Additionally, if high stress is unloaded in a short time, the energy stored in the rock will also be relieved suddenly, which may induce some dynamical disasters. Conversely, with the same loading path, the ratio $U^{e} / U$ increases with the treated temperature increasing from room temperature to $300{ }^{\circ} \mathrm{C}$, and declines with the temperature increasing from $300{ }^{\circ} \mathrm{C}$ to $900{ }^{\circ} \mathrm{C}$. That outcome indicates that granite undergoing $300{ }^{\circ} \mathrm{C}$ displays the highest efficiency of energy absorption and accumulation.

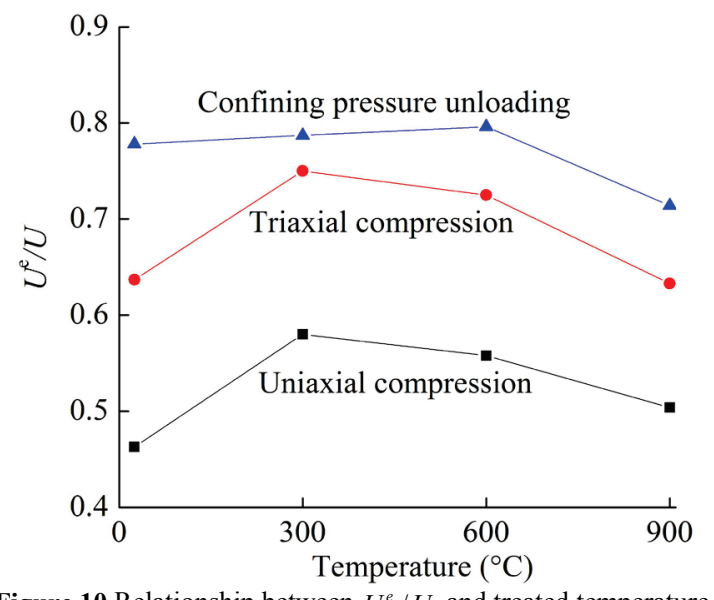

Figure 10 Relationship between $U^{e} / U$ and treated temperature

\section{Conclusions}

To investigate the effects of heat treatment on mechanical properties and energy features of granite samples under three different loading paths, 12 groups of experiments were conducted on granite after heat treatment under uniaxial compression, triaxial compression, and confining pressure unloading condition in this research. Based on the experimental results, the following conclusions can be drawn:

(1) The complete stress-strain curves in these three loading paths can be characterized into several stages based on their shape features. The Young's modulus and the uniaxial compressive strength of the granite samples are positively correlated with the treated temperature at relatively low levels, but negatively correlated with the temperature at a relatively high level.

(2) For a certain temperature, the granite samples have different trends of energy evolution at each stage of the stress-strain process in all three loading paths. The energy features show similar tendency in all temperature cases.

(3) The total absorbed energy, the dissipated energy, and the peak values of elastic strain energy after failure appear as convex shapes, and the peaks of these three characteristic energy values under all of the three different loading paths occur at approximately $300{ }^{\circ} \mathrm{C}$.
The conclusions in this study, which reveal the mechanical properties and energy evolution features of rock after exposure to high temperature in different loading paths, are beneficial for giving a reference for designing and constructing underground rock engineering involving high temperature. However, the corresponding numerical model cannot be established due to the small number of temperature settings. More tests with various temperature settings will be required in the future to establish a precise constitutive model for the quantitative calculation and deformation prediction in actual underground projects.

\section{Acknowledgement}

The study was financially supported by the National Key Research and Development Program (2016YFC0600901).

\section{References}

[1] Dvorakova, M.; Vencl, M.; Becvarikova, T. Deep geological repository for disposal of nuclear waste in the Czech Republic // International Youth Conference on Energy. / IEEE, 2015, pp. 1-4.

[2] Hudson, J. A.; Stephansson, O.; Andersson, J. Guidance on numerical modeling of thermo-hydro-mechanical coupled processes for performance assessment of radioactive waste repositories. // International Journal of Rock Mechanics and Mining Sciences. 42, 5-6(2005), pp. 850-870.

[3] Johnson, B.; Newman, A.; King, J. Optimizing high-level nuclear waste disposal within a deep geologic repository. // Annals of Operations Research. 252, 333(2016), pp. 1-23.

[4] Genter, A.; Evans, K.; Cuenot, N. et al. Contribution of the exploration of deep crystalline fractured reservoir of Soultz to the knowledge of enhanced geothermal systems (EGS). // Comptes Rendus Geosciences. 342, 7 (2010), pp. 502-516. https://doi.org/10.1016/j.crte.2010.01.006

[5] Meller, C.; Kohl, T. The significance of hydrothermal alteration zones for the mechanical behavior of a geothermal reservoir. // Geothermal Energy. 2, 1(2014), paper No. 21

[6] Jiang, P.; Zhang, L.; Xu, R. Experimental study of convective heat transfer of carbon dioxide at supercritical pressures in a horizontal rock fracture and its application to enhanced geothermal systems. // Applied Thermal Engineering. 117, (2017), pp. 39-49. https://doi.org/10.1016/j.applthermaleng.2017.01.078

[7] Heap, M. J.; Baud, P.; Meredith, P. G. et al. Brittle creep in basalt and its application to time-dependent volcano deformation. // Earth \& Planetary Science Letters. 307, 12(2011), pp. 71-82.

[8] Sengun, N. Influence of thermal damage on the physical and mechanical properties of carbonate rocks. // Arabian Journal of Geosciences. 7, 12(2014), pp. 1-9. https://doi.org/10.1007/s12517-013-1177-x

[9] Tian, H.; Kempka, T.; Xu, N. X. et al. Physical properties of sandstones after high temperature treatment. // Rock Mechanics \& Rock Engineering. 45, 6(2012), pp. 11131117. https://doi.org/10.1007/s00603-012-0228-z

[10] Tian, H.; Kempka, T.; Yu, S. et al. Mechanical properties of sandstones exposed to high temperature. // Rock Mechanics \& Rock Engineering. 49, 1(2016), pp. 321-327. https://doi.org/10.1007/s00603-015-0724-z

[11] Tian, H.; Mei, G.; Jiang, G. S. et al. High-temperature influence on mechanical properties of diorite. // Rock Mechanics \& Rock Engineering. (2017), pp. 1-6. https://doi.org/10.1007/s00603-017-1185-3 
[12] Ganne, P.; Vervoort, A. Effect of stress path on pre-peak damage in rock induced by macro-compressive and -tensile stress fields. // International Journal of Fracture. 144, 2(2007), pp. 77-89. https://doi.org/10.1007/s10704-007-9081-6

[13] Fredrich, J. T.; Wong, T. F. Micromechanics of thermally induced cracking in three crustal rocks. // Journal of Geophysical Research Solid Earth. 91, B12(1986), pp. 12743-12764. https://doi.org/10.1029/JB091iB12p12743

[14] Géraud, Y.; Mazerolle, F.; Raynaud, A. Comparison between connected and overall porosity of thermally stressed granites. // Journal of Structural Geology. 14, 89(1992), pp. 981-990. https://doi.org/10.1016/0191-8141(92)90029-V

[15] Géraud, Y. Variations of connected porosity and inferred permeability in a thermally cracked granite. // Geophysical Research Letters. 21, 11(1994), pp. 979-982. https://doi.org/10.1029/94GL00642

[16] Yavuz, H.; Demirdag, S.; Caran, S. Thermal effect on the physical properties of carbonate rocks. // International Journal of Rock Mechanics and Mining Sciences. 47, 1 (2010), pp. 94-103. https://doi.org/10.1016/j.jirmms.2009.09.014

[17] Zhang, W.; Sun, Q.; Hao, S. et al. Experimental study on the thermal damage characteristics of limestone and underlying mechanism. // Rock Mechanics \& Rock Engineering. 49, 8(2016), pp. 2999-3008. https://doi.org/10.1007/s00603-016-0983-3

[18] Yu, J.; Chen, S. J.; Chen, X. et al. Experimental investigation on mechanical properties and permeability evolution of red sandstone after heat treatments. // Journal of Zhejiang University-SCIENCE A. 16, 9(2015), pp. 749759. https://doi.org/10.1631/jzus.A1400362

[19] Yang, S. Q.; Ranjith, P. G.; Jing, H. W. et al. An experimental investigation on thermal damage and failure mechanical behavior of granite after exposure to different high temperature treatments. // Geothermics. 265, (2017), pp. 180-197. https://doi.org/10.1016/j.geothermics.2016.09.008

[20] Su, G.; Chen, Z.; Ju, J. W. et al. Influence of temperature on the strainburst characteristics of granite under true triaxial loading conditions. // Engineering Geology. 222, (2017), pp. 38-52. https://doi.org/10.1016/j.enggeo.2017.03.021

[21] Ranjith, P. G.; Viete, D. R.; Chen, B. J. et al. Transformation plasticity and the effect of temperature on the mechanical behaviour of hawkesbury sandstone at atmospheric pressure. // Engineering Geology. 151, 151(2012), pp. 120-127.

[22] Shao, S.; Ranjith, P. G.; Wasantha, P. L. P. et al. Experimental and numerical studies on the mechanical behaviour of Australian Strathbogie granite at high temperatures: An application to geothermal energy. // Geothermics. 54, 54(2015), pp. 96-108. https://doi.org/10.1016/j.geothermics.2014.11.005

[23] Zhang, Y.; Chen, Y.; Yu, R. et al. Effect of Loading Rate on the Felicity Effect of Three Rock Types. // Rock Mechanics \& Rock Engineering, (2017), pp. 1-9. https://doi.org/10.1007/s00603-017-1178-2

[24] Wanne, T. S.; Young, R. P. Bonded-particle modeling of thermally fractured granite. // International Journal of Rock Mechanics \& Mining Sciences. 45, 5(2008), pp. 789-799. https://doi.org/10.1016/j.jijmms.2007.09.004

[25] Wanne, T. Bonded-particle modeling of thermally induced damage in rock. // Christianity \& Culture. 26, 3(2009), pp. 251-258.

[26] Yu, Q. L.; Ranjith, P. G.; Liu, H. Y. et al. A mesostructurebased damage model for thermal cracking analysis and application in granite at elevated temperatures. // Rock Mechanics \& Rock Engineering. 48, 6 (2015), pp. 22632282. https://doi.org/10.1007/s00603-014-0679-5

[27] Pan, P.; Feng, X. Numerical study on coupled thermomechanical processes in Äspö Pillar Stability Experiment. //
Journal of Rock Mechanics and Geotechnical Engineering. 5, 2(2013), pp. 136-144. https://doi.org/10.1016/j.jmge.2013.02.001

[28] Solecki, R.; Conant, R. J. Advanced mechanics of materials. Oxford University Press, London, 2003.

[29] Wang, J. A.; Park, H. D. Fluid permeability of sedimentary rocks in a complete stress-strain process. // Engineering Geology. 63, 3(2002), pp. 291-300. https://doi.org/10.1016/S0013-7952(01)00088-6

[30] Yu, J.; Li, H.; Chen, X. et al. Experimental study of permeability and acoustic emission characteristics of sandstone during processes of unloading confining pressure and deformation. // Chinese Journal of Rock Mechanics and Engineering. 33, 1(2014), pp. 69-79. (in Chinese)

[31] Konicek, P.; Soucek, K.; Stas, L. et al. Long-hole destress blasting for rockburst control during deep underground coal mining. International // Journal of Rock Mechanics and Mining Sciences. 61, (2013), pp. 141-153. https://doi.org/10.1016/j.jijmms.2013.02.001

[32] Łukasz, W.; Konicek, P. Estimation of active rockburst prevention effectiveness during longwall mining under disadvantageous geological and mining conditions. // Journal of Sustainable Mining. 15, 1(2016), pp. 1-7. https://doi.org/10.1016/j.jsm.2016.04.003

[33] Meng, F.; Zhou, H.; Wang, Z. et al. Experimental study on the prediction of rockburst hazards induced by dynamic structural plane shearing in deeply buried hard rock tunnels. // International Journal of Rock Mechanics and Mining Sciences. 86, (2016), pp. 210-223. https://doi.org/10.1016/j.jijmms.2016.04.013

[34] Xiao, Y. X.; Feng, X. T.; Li, S. J. et al. Rock mass failure mechanisms during the evolution process of rockbursts in tunnels. // International Journal of Rock Mechanics and Mining Sciences. 83, (2016), pp. 174-181. https://doi.org/10.1016/j.jirmms.2016.01.008

\section{Authors' addresses}

Jun-wen Zhang, Ph.D., Associate Professor College of Resource and Safety Engineering, China University of Mining and Technology, D11, Xueyuan Road, Haidian District, Beijing, 100083, P. R. China E-mail: Zhangjunwen1977@163.com

\author{
Xu Chen, Ph.D. Candidate \\ (Corresponding author) \\ School of Resources and Civil Engineering, \\ Northeastern University, \\ No. 3-11, Wenhua Road, Heping District, \\ Shenyang, Liaoning, 110819, P. R. China \\ E-mail: goodmancx@sina.com \\ Heng-yi Kang, Ph.D. Candidate \\ Department of Civil Engineering, \\ University of Hong Kong, \\ LG04, Haking Wong Building, Pokfulam, \\ Hong Kong SAR, P. R. China \\ E-mail: hykang@connect.hku.hk
}

